\title{
MEMÓRIA E ALTERIDADE EM DOIS CONTOS DE CAIO FERNANDO ABREU
}

Guilherme Zubaran de Azevedo*
* guilhermezubaran@yahoo.com.br

Aluno de Doutorado do Programa de Pós-Graduação em Estudos Literários da Universidade Federal de Minas Gerais.
RESUMO: Este trabalho pretende analisar as manifestações da alteridade em dois contos, inseridos no livro Os dragões não conhecem o paraíso, escrito por Caio Fernando Abreu. Para tanto, é importante pensar as condições intervalares dos sujeitos sociais que vivem experiências femininas e homoafetivas recuperadas pela atividade da memória. Constituídas pelos sentimentos de perda e de dor, essas experiências da alteridade revelam seu caráter político, pois apresentam relações de afeto que não se enquadram nas gramáticas sociais.

PALAVRAS-CHAVE: memória; alteridade; sujeito.
ABSTRACT: This study aims to examine the manifestations of otherness in two stories, inserted in the book Os Dragões não conhecem o paraíso, written by Caio Fernando Abreu. Therefore, it is important to think about the conditions interval of social subjects living female experiences and homoafetivas recovered by the activity of memory. Constituted by feelings of loss and pain, these experiences of otherness reveal their political character, since they have relationships of affection that do not fit the social grammars.

KEYWORDS: memory; othernes; , subject. 
O presente trabalho tem como objetivo analisar dois contos do livro Os dragões não conhecem o paraíso, do escritor Caio Fernando Abreu a fim de propor uma leitura política das relações afetivas encenadas nessas histórias. O sentido político não se vincula à ideia de Estado e partido, mas, possui uma dimensão relativa às memórias e às vivências de grupos subalternos que vivem identidades fraturadas no tempo e no espaço.

Analisar a produção literária contemporânea exige a discussão a respeito das configurações políticas e culturais atuais, marcadas pela aceleração da circulação da informação - proporcionada pelos avanços dos meios de comunicação e direcionadas conforme os objetivos políticos e econômicos das empresas - e pela expansão do mercado de consumo fragmentando a sensação temporal e espacial do vivido. Esse processo se realiza por meio de um mercado global de produção de bens culturais relacionados com a memória passado virou mercadoria (HUYSSEN, 2000) - e, ao mesmo tempo, se caracteriza por um esvaziamento da condição histórica por meio da qual se evidencia uma amnésia socia (MIRANDA, 2010). Daí a constituição de uma experiência coletiva, fraturada em suas noções de espaço e tempo que vivencia uma memória/mercadoria - "os passados dispensáveis” (HUYSSEN, 2000, p.37) - e, muitas vezes, não efetiva uma recordação produtiva - "os passados usáveis" (HUYSSEN, 2000, p. 37) - vinculada aos conflitos e às demandas políticas dos diferentes grupos socais.
As relações entre o global e o local, nesse cenário pós-moderno, apresentam uma instabilidade materializada no deslocamento da dicotomia tradicional entre centro/periferia, uma vez que as formas de transmissão e recepção da informação são ressignificadas a partir da perspectiva de atores sociais, cujas identidades e demandas evidenciam a diferença cultural. Desse modo, o estabelecimento de totalidades consensuais - cuja finalidade repousa na construção de uma homogeneidade moderna, realizada por meio de dispositivos nacionais e etnocêntricos, - sofre uma ruptura com a atividade do trabalho de rememoração pós-moderna pelo qual as memórias, reprimidas pela modernidade, emergem para configurar novas verdades localizadas e transitó rias (MIRANDA, 2010). O pós-moderno, segundo Bhabha (1998), aponta os limites epistêmicos da modernidade a fim de liberar outras vozes dissonantes que foram sufocadas pelas verdades científicas e coloniais do mundo ocidental. A experiência fraturada, assim, abre a possibilidade de se escapar dos consensos, na medida em que as tradições locais efetivam uma recordação desses conteúdos recalcados:

A ação de retomada dessas tradições locais intervém nesse processo enquanto ato de recuperação mnemônica que visa opor-se à noção de unidade cultural uniforme e centralizadora, abrindo caminho para a individuação de práticas localizadas e diferenciadas. Trata-se de um trabalho de memória interessado na

$\begin{array}{llllll}\text { EM TESE } & \text { BELO HORIZONTE } & \text { v. } 19 & \text { N. } 3 & \text { SET.-DEz. } 2013 & \text { AZEVEDO. Memória e alteridade em dois contos de Caio Fernando Abreu }\end{array}$

\section{Ensino e teoria}


apreensão dos mecanismos através dos quais tradições diversificadas se transformam, construindo-se e desconstruindo-se no seu processo de conformação. (MIRANDA, 2010, p. 105)

O olhar rememorativo possibilita a emergência da perspectiva significante do outro que ocupa um espaço de enunciação conflituoso e híbrido, capaz de elaborar histórias através das quais se rearticulam o conjunto de significantes da cultura, de modo a encenar o entre-lugar da experiência coletiva subalterna. Esse ato discursivo, redimensionando noção de política e de poder - conforme o caminho proposto por Foucault (1979) -, materializa a atividade enunciativa da minoria, cujo olhar evidencia o seu lugar de sujeito do conhecimento e da narração. Bhabha (1998, p. 247/248) descreve esse movimento de racionalidade mínima:

A racionalidade mínima, [...], altera o sujeito da cultura, transformando-o de função epistemológica em uma prática enunciativa. [...] a cultura como enunciação se concentra na significação e na institucionalização; [...], o enunciativo tenta repetidamente reinscrever e relocar a reivindicação política de prioridade e hierarquia culturais (alto/baixo, nosso/deles) na instituição socia da atividade de significação. [...]. O enunciativo é um processo mais dialógico que tenta rastrear deslocamentos e realinhamentos que são resultado de antagonismos e articulações culturais - subvertendo a razão do momento hegemônico e recolocando lugares híbridos, alternativos, de negociação cultural.
A característica enunciativa da textualidade não tem como objetivo a construção de um conhecimento empírico do mundo, que visa à elaboração de um enunciado transparente da realidade; o seu olhar, segundo Barthes (2007, p. 20), se concentra nas articulações de significação da linguagem; no manejo das palavras "lançadas como projeções, explosões, vibrações, maquinarias, sabores”; no lugar do sujeito, situado entre o desconhecido e o reconhecido (BARTHES, 2007 , p.20). O conceito de enunciação possibilita, assim, a emergência da diferença cultural que - diferente da ideia de diversidade - coloca em questão a capacidade da autoridade em definir a estabilidade e a coesão dos sistemas sociais, provocando um deslizamento do tempo tradicional - a entrada em cena das temporalidades disjuntivas - e a configuração de narrativas que encenam a cisão desses sujeitos.

Desse modo, a tradição moderna é interpelada por novas estratégias conflituosas e antagônicas de subjetivação de sujeitos sociais da minoria, cuja atividade mnemônica produz as fissuras no continuum histórico, provocando a emergência de outras temporalidades capazes de prefigurar uma experiência ex-cêntrica do presente. Daí a formação de uma rede de metáforas ligadas ao interstício, à fronteira, ao hibridismo e ao entre-lugar, que expressam não apenas esse redimensionamento do tempo, nos termos de Bhabha (1998), mas, sobretudo, a forma de apresentar a condição intervalar da alteridade cultural.

\section{Ensino e teoria}


A articulação do signo cultural perde seu caráter totalizador e unificador de uma comunidade, nação, classe, raça e gênero pela irrupção dessas temporalidades disjuntivas vinculadas às posições da marginalidade. Assim, a estabilidade dos sistemas de representação - configurados em torno de dispositivos liberais de tolerância e consenso - sofre um processo de questionamento a partir do ato enunciativo de identidades subalternas, localizadas em zonas limiares da cultura, cuja produção discursiva revela o seu caráter agônico. Essas formas de subjetividade, de acordo com Bhabha (1998), apresentam o seu sentido contestatório por meio da produtividade de contra-saberes capazes de deslocar os binarismos e as polaridades da vida cotidiana, apresentando uma estratégia de significação política marcada pela ambivalência e pelo dissenso.

Esse processo de negociação cultural se expressa em termos performáticos e tradutórios, uma vez que há, de um lado, uma quebra dos modos tradicionais de identificação e afiliação social e, de outro, um desvio das estratégias de significação do mundo e da sociedade. Essa operação atua no sentido de produzir representações simbólicas residuais que apresentam uma imagem do social atravessada pela heterogeneidade dos grupos subalternos.

A operação de fazer falar a voz de outrem se insere no campo de força da representação e dos agenciamentos das vozes legitimadas na sociedade. Regina Dalcastagnè (2002) assinala que os códigos literários são acessados por grupos de elite, os quais têm o poder de delimitar discursivamente as condições de existência dos marginalizados. Essas percepções sobre o outro, na verdade, refletem as posições dos escritores da classe média brasileira. Entretanto, essa política de silenciamento do subalterno, cuja ação se impõe com mais violência sobre as mulheres, como analisa Spivak (2010), é contraposta pela construção de uma perspectiva causadora de um estranhamento, na medida em que revela novos enfoques das situações cotidianas (DALCASTAGNÈ, 2002, p. 54). Essa tarefa de tradução do texto literário busca desvendar, de modo crítico, as formas de figuração da subalternidade, o que Spivak (2010, p. 84) denomina de mecânica da constituição do outro.

$\mathrm{O}$ ato político do processo tradutório se concretiza na elaboração de uma textualidade performativa que, segundo Graciela Ravetti (2002, p. 49), confronta as categorias identitárias delimitadas e definidas pelos dispositivos e instituições de poder:

Considero performativa a narrativa que apresenta um cenário no qual um (ou mais) sujeito(s) aparece(m) em processos de atribuição, com referentes explícitos à realidade material, sendo, por isso, identificáveis, mas nas quais os comportamentos narrados (afinal trata-se de comportamentos sociais) são, no mínimo, transgressores quanto à ordem vigente.

\section{Ensino e teoria}


O elemento transgressor dessa ficção articula o local dos sujeitos da enunciação, os comportamentos íntimos, as significações políticas do corpo e do gênero para configurar uma escrita híbrida, não apenas na incorporação de diversos suportes, mas também na encenação das diversas vozes implicadas na mobilização da resistência e na imposição das linguagens sociais. Esse jogo agônico entre as resistências populares e a gramática disciplinar é desenvolvido por uma forma de escrita que aciona a memória para restituir os restos, as ruínas e os resíduos do mundo pretérito, seguindo as metáforas benjaminianas, com a finalidade de apresentar os lampejos ou as pequenas intermitências das experiências clandestinas desses sujeitos (DIDI-HUBERMANN, 2011, p. 148/149). O caráter testemunhal dos restos dessas experiências extrapola a dimensão individual, abrindo a possibilidade, metonimicamente, de uma via de leitura para um contexto geral, através do qual se desenha uma cartografia estética, sentimental e, sobretudo, dos modos de existência (RAVETTI, 2002, p. 56).

As memórias de combate contra as regras governamentais mostram as disputas em torno da sexualidade, travadas com o surgimento dos movimentos feministas, gays, lésbicos e transgêneros que lutam por formas de existência não inseridas no padrão heteronormativo, propagado pela medicina, religião e meios de comunicação. A guerra contra o preconceito, a exclusão e por igualdade de direitos reflete o redimensionamento da intimidade, que passa a ser um espaço em que as relações de afeto adquirem um valor político, visto que não são todas as vivências afetivas que são permitidas pela sociedade.

A sexualidade, segundo Foucault $(1979 ; 2012)$, se torna um dispositivo fundamental de poder, no mundo ocidental, pelo qual se produz uma rede de verdade capaz delimitar e regrar as condutas humanas. A experiência sexual do indivíduo é construída a partir "dos campos de saber, tipos de normatização e formas de subjetivação" (FOUCAULT, 2012, p. 188). Assim, o sexo - objeto de uma multiplicidade de saberes - se torna o meio através do qual se estabelece a verdadeira identidade do sujeito, não deixando espaço para comportamentos ambíguos e muito menos para o estímulo do prazer. Foucault (2012) destaca que a intimidade e o elemento confessional se tornam objeto de práticas do poder pastoral e das técnicas de si para produzir um controle das experiências sexuais, do desejo e libido. Dessa maneira, a sexualidade materializa as acões de governamentalidade cujos processos de sujeição efetivam efeitos de poder na constituição dos corpos, dos desejos e das vontades.

As possibilidades de resistência histórica se concretizam por meio de ações dos sujeitos que buscam escapar dos jogos de controle e dominação. No primeiro momento histórico desses

\section{Ensino e teoria}


movimentos, situado por Denilson Lopes (2004) na década de 1960, o objetivo de luta se direcionava contras os estereótipos e os modos de silenciamento a fim de criticar as posições machistas e homofóbicas e, consequentemente, defender uma diversidade de expressão da sexualidade não reduzida ao binário biológico masculino/feminino. No entanto, Denilson Lopes (2004, p. 66) observa que a estratégia de representação identitária contra os estigmas foi incorporada pela indústria cultural que passou a construir novas formas de estereótipos com a elaboração de personagens gays idealizados.

A defesa do feminismo e da homossexualidade desempenhou o papel relevante de combate às práticas de violências machistas e homofóbicas. Contudo, Denílson Lope (2004, p. 70) propõe a discussão de modos de afeto mais sutis que, escapando de posições confrontacionais, se efetivam na complexidade diária de viver a sexualidade. Daí o termo "homoafetividade" (LOPES, 2001, p. 70) para analisar os comportamentos de pessoas do mesmo sexo, sem cair na polaridade homossexualidade/heterossexualidade. Essas vivências sexuais se libertam das categorias normativas, segundo Foucault, a partir de uma cultura do prazer, cuja realização se materializa num "espaço vazio" enriquecedor das relações afetivas, de tal maneira que "as pessoas não homossexuais poderão enriquecer suas vidas modificando seu próprio esquema de relação" (FOUCAULT, 2012, p. 119).
No Brasil, a obra do escritor Caio Fernando Abreu acompanha a historicidade de lutas em torno da questão da sexualidade, criando representações simbólicas críticas aos clichês de gênero que circulam na sociedade. De modo geral, as suas narrativas constroem uma perspectiva subjetiva e intimista a fim de questionar, conforme Bruno Souza Leal (2002, p. 87) a respeito dos cinco primeiros livros de contos, as condições de estar-no-mundo, sempre por meio de um olhar de fora, descentrado: "o processo que se elabora no conjunto dos cinco livros tem um [...] aspecto de individualização crescente, resultado de uma tentativa permanente, [...], de localização no mundo, de afirmação de uma singularidade frente a diversidade do Eu."

Os primeiros três livros de contos - $O$ inventário do irremediável, $O$ ovo apunhalado e Pedras de Calcutá, publicados na década de 1970, - possuem o caráter representativo do grupo de jovens envolvidos nas demandas contraculturais contrárias à ordem autoritária então vigente, daí a delimitação mais clara dos lugares de enunciação desses sujeitos. Na sequência, o projeto coletivo perde força em favor de um ponto de vista individualizado a partir de um mergulho na subjetividade, em cujo espaço se refletem não apenas as desilusões com o ideário da década de 70, tal como é encenado na parte do mofo em Morangos Mofados (1983), mas, sobretudo, o entre-lugar de sujeitos anônimos que transitam pela metrópole, vivenciando a fratura das máscaras sexuais e dos estigmas sociais.

\section{Ensino e teoria}


O último livro de contos, Os dragões não conhecem o paraíso, apresenta a perspectiva relativa à politização da experiência privada desses indivíduos excluídos e ex-cêntricos. Publicado em 1988, a obra é composta de 13 narrativas, interligadas entre si como um romance-móbile, de acordo com o próprio autor. Suas histórias se concentram nas vivências individuais, em que a sexualidade já não é mais vista a partir de um projeto político coletivo, mas como um processo de desmascaramento dos estigmas e submissões do cotidiano. Os personagens aparecem deslocados da fixidez identitária, e a narrativização do vivido é despertada pelos sentimentos de perda e solidão. Com isso, a memória e o trauma se constituem nos dispositivos de enunciação das existências femininas e homoafetivas.

A visão da mulher enquanto sujeito - e não objeto - da enunciação aparece no conto Os sapatinhos vermelhos. A história narra a trajetória da personagem Adelina cujo relacionamento foi rompido pelo companheiro. Em sua casa, às vésperas da Sexta-Feira Santa, ela vive a angústia da solidão aos quarenta anos de idade. Desse modo, o seu estado agônico dispara as reminiscências de momentos e sentimentos relacionados com o parceiro, em que os vínculos tradicionais de gênero se mostram bem cristalizados como na seguinte lembrança: "A putinha submissa a coreografar jantares à luz de velas - Glenn Miller ou Charles Aznavour? -, vertendo trêfega os sais - camomila ou alfazema? - na água da banheira, preparando uísques - uma ou duas pedras hoje, meu bem?” (ABREU, 2010, p. 82). A descrição da cena é acompanhada pelo olhar do narrador que, em várias partes, se mistura com o ponto de vista da personagem, mostrando uma forma de identificação em que a terceira pessoa daquele se aproxima da primeira pessoa desta. Ou seja, a voz do narrador deixa de tratar a personagem como objeto, se incorporando à perspectiva desta.

A cena privada evidencia a naturalização do sujeito feminino, atrelada à visão de dominação masculina para a qual a mulher se restringe aos cuidados da casa, dos rituais do casal e do próprio parceiro. Além disso, a referência aos dois cantores da canção popular americana e francesa, dialogando com a cultura de massa, se agrega ao código normativo do feminino, demonstrando uma maneira sentimentalizada de viver a relação. $O$ signo tradicional do gênero sofre uma fissura performática quando ocorre a ruptura do relacionamento, já que é a condição de solitária que opera a quebra da sua identidade:

Vampira, envelheceria séculos lentamente até desfazer-se em pó aos pés impassíveis dele. Mas ao contrário, tão desamparada e descalça, quase nua, sem maquilagem nem anjo de guar$\mathrm{da}$, dentro de uma camisola velha de pelúcia, às vésperas da

\section{Ensino e teoria}


Sexta-Feira Santa, sozinha no apartamento e no planeta terra (ABREU, 2002, p. 83)

O desamparo e a solidão atuam no sentido de afastá-la da dependência com o homem, deixando de ser apenas um apêndice da existência masculina. A ruptura do signo essencialista do gênero se materializa, também, na enunciação do seu corpo. Segundo Sandra Goulart de Almeida (2012), o corpo da mulher é objeto de discursos heteronormativos, enraizando-o como um território da nação, da terra natal, do matrimônio e da maternidade. Esses significantes são projeções discursivas que atuam no sentido de delimitar as condições de existência do corpo da mulher. Nessa passagem, a descrição física da personagem - sem maquilagem, quase nua, vampira - possui um sentido performático, pois teatraliza a sua marca pessoal, o que abre espaço para um campo da constituição da diferença e do reconhecimento político da sua trajetória individual.

Os restos do relacionamento povoam não apenas a sub jetividade da personagem, mas o próprio espaço da casa. $\mathrm{Na}$ agonia da solidão, ela olha para os seus pés e se lembra dos sapatinhos vermelhos, dados de presente pelo parceiro. Os sapatos materializam os rastros, os vestígios, desse relacionamento. Esse objeto contém uma dimensão ambígua, materializada na dicotomia do presente/ausente, uma vez que a sua presença, no momento da enunciação, remete para um tempo perdido do vivido. O fragmento, em termos benjaminianos, propicia uma maneira "de pensar a existência à luz das perdas" (GINZBURG, 2012, p. 109), impulsionando a personagem a refletir sobre sua vida. Na verdade, Judith Butler (2003) afirma que a unidade entre gênero, sexo e desejo - disciplinados pelo heteronormatividade - se quebra a partir da presença do inconsciente, de cujo espaço emergem os conteúdos recalcados capazes de fraturar a coerência dos sujeitos. Os sapatos disparam a irrupção das reminiscências, o que motiva a ação da personagem, estabelecendo uma quebra com o início da narrativa:

Viu-se no espelho de má qualidade, meio deformada a distância, uma mulher descabelada jogando caixas e roupas para os lados até encontrar, na terceira gaveta do armário, o embrulho em pape de seda azul-clarinho. (ABREU, 2010, p. 84)

Perfeitamente: Adelina colocou um disco - nem Charles Aznavour, nem Glenn Miller, mas uma úmida Billie Holiday, Im glad, yoú re bad, [...], depois deixou a banheira encher aos poucos de suave água morna, salpicou os sais antes de mergulhar, [...], e lavou todos os orifícios, e também os cabelos, todos os cabelos, enfrentou o chuveiro frio, secou o corpo e cabelos enquanto esmaltava as unhas dos pés, das mãos, no mesmo tom de vermelho dos sapatos, mais tarde desenhou melhor a boca, já dentro do vestido preto justo. (ABREU, 2010, p. 85)

\section{Ensino e teoria}


O corpo, outra vez, encena a dinâmica da subjetividade da personagem. Na primeira parte, ela aparece deformada. Após encontrar os sapatos vermelhos, ela lembra que a coloração era muito ousada para o seu tipo de mulher, cuja identidade de pessoa recatada fazia-a também evitar roupas muito decotadas. Esses cuidados refletiam uma tentativa de esconder sua verdadeira identidade de "mulher-solteira-independente-que-tem-umamante-casado" (ABREU, 2010, p 84). A forma de escrita, em que os elementos aparecem juntos pela presença do hífen, expõe um enunciado cristalizado como um clichê. Na verdade, ela não era independente dele ao contrário, a personagem vive uma máscara social que a condiciona a um tipo de laço afetivo com o parceiro e a um modo de ser diante da sociedade.

No segundo trecho, após pegar os sapatos, há uma mudança de atitude, introduzida pela marca do advérbio, como início de outra forma de performance da personagem. A troca da música para Billie Holiday e o arranjo da banheira para o seu uso evidenciam o novo lugar de enunciação desse sujeito. O corpo limpo e a roupa sensual rompem com a imagem de mulher recatada, que vive em função do companheiro, apresentando-a como sujeito aberto a novas trajetórias e vivências, o que demonstra a força dos elementos reprimidos para deslocar o comportamento da personagem. Essa nova

experiência se realiza no momento em que ela sai de casa e vai para uma boate, onde conhece três homens.

A relação com os homens se modifica. Primeiro, ela encontra um rapaz negro. Há um jogo de sedução entre os dois $\mathrm{Na}$ sequência, ela demonstra interesse em conhecer os dois amigos do moço, o que causa estranhamento neste. Por fim, quando estão saindo do local, um dos personagens pergunta com quem ela quer sair, e a personagem responde: "com os três, ora" (ABREU, 2012, p. 91). Há um posicionamento diferente com relação ao sexo, espaço em que a mulher, segundo Pierre Bourdieu (2011), se coloca de modo passivo. No conto, a personagem propõe transar com os três, o que causa surpresa nos homens. A cena do sexo evidencia a postura ativa da personagem:

O negro veio por trás, que gostava assim, tão apertadinho. Ela nunca tinha feito, mas ele jurou no ouvido que seria cuidadoso, depois mordeu-a nos ombros, enquanto a virava de perfil, muito suavemente, molhando-a de saliva com o dedo, para que mais baixo pudesse continuar a lambê-la entre as coxas, enquanto o tenista-dourado, de joelhos, esfregava o pau no rosto dela, até encontrar a boca. (ABREU, 2010, p. 92)

De outros jeitos, de todos os jeitos: quatro, cinco vezes. Em pé, no banheiro, tentando aplacar-se embaixo da água fria do

\section{Ensino e teoria}


chuveiro. Na sala, de quatro nas almofadas de cetim, sobre o sofá depois do chão. [...]. em frente ao espelho de corpo inteiro do corredor, sem se chocar que o mais baixo de repente viesse também por trás do tenista-dourado dentro dela, que acariciava o pau do negro até que espirasse em jatos sobre os sapatos vermelhos dela, que abraçava os três, não era mais Gilda, nem Adelina nem nada. Era um corpo sem nome, varado de prazer, coberto de marcas de dentes e unhas, lanhado dos tocos das barbas amanhecidas, lambuzada do leite sem dono dos machos da rua. Completamente satisfeita. E vingada. (ABREU, 2010, p. 93)

Num primeiro momento, o vocabulário e as descrições das posições parecem apresentar uma imagem banal da sexualidade, como analisa Bruno Souza Leal (2002). No entanto, a variedade de formas de relacionamento sexual materializa uma escrita que encena a vertigem de uma subjetividade que habita o entre-lugar, na medida em que os enquadramentos e as modalidades do sexo convergem para a manifestação de um desejo que escapa a gramática sexual da ordem masculina. A experimentação de outros prazeres desnaturaliza a dinâmica de divisão e classificação social do gênero que, conforme Pierre Bourdieu (2011), organiza o desejo pela oposição ativo/passivo, como uma forma de posse, de confirmação da virilidade do homem, em que a vontade da mulher se coloca em situação de subordinação.
A textualização do corpo atua como um performance capaz de expressar gestos que se articulam num prazer visceral, cujos rastros se inscrevem na pele, rasgada pelas unhas e pela barba, onde permanecem os resíduos do gozo. O corpo teatraliza o entre-lugar, o não nomeado, o que não se insere, como afirma Barthes (2007) e Ravetti (2002), na lógica do poder da linguagem capaz de delimitar a repetição gregária dos comportamentos. A personagem sem dono, sem nome, cuja experiência narra o vazio, retomando a ideia de Foucault, de um prazer sexual em trânsito.

No final da história, a experimentação de uma sexualidade visceral possibilita a emergência da violência do antigo parceiro que se manifesta na sua visita, no dia seguinte. Ela, entretanto, o manda embora, o que gera uma reação agressiva dele: "Havia um cheiro de cigarro e bebida e gozo entranhado pelos cantos do apartamento, a cara de ressaca dela, manchas-roxas de chupões no colo. Pela primeira vez única, e última vez ele a chamou muitas vezes de puta, puta vadia, puta escrota depravada pervertida" (ABREU, 2012, p. 94).

A violência simbólica do machismo demonstra a característica política da ética do prazer praticada pela personagem. O uso de vocabulários como puta, vadia, depravada e pervertida revela uma maneira de interpelação desse comportamento sexual desviante no sentido de enquadrá-lo dentro de um estigma. Entretanto, a singularidade da personagem

\section{Ensino e teoria}


- "pela primeira vez única” - escapa dessa gramática discursiva e efetiva o entre-lugar de sua experiência, vivida na tensão entre o código normativo e a realização de desejos sexuais outros. É nesse interstício cultural em que se ilumina a clandestinidade dessa vivência feminina.

A condição intervalar da alteridade homoafetiva é representada no conto Uma praiazinha de areia bem clara, ali, na beira da sanga. A epígrafe do conto, each man kills the things he loves - uma frase retirada de um filme do cineasta alemão Fassbinder, já remete à ideia de morte e amor, o que indica a presença de um campo semântico relativo à perda, à melancolia e à solidão. No inicio da narrativa, o narrador aparece escrevendo uma carta para um amigo, o Dudu, que ainda mora na cidade pequena, chamada de Passa da Guanxuma, onde os dois conviveram boa parte de suas vidas. Morando no presente da enunciação, numa metrópole, o narrador, ao olhar pela janela de seu apartamento, sente o peso do anonimato e da indiferença:

Agora olhei pela janela. A janela do meu quarto dá para os fundos de outro edifício, fica sempre um ar cinzento preso naquele espaço. [...]. Se você estivesse aqui e olhasse para a frente, veria uma porção de janelinhas de banheiro, tão pequena que nem dá para espiar o monte de sacanagem que devem acontecer por trás delas. Se você olhasse para baixo, veria aquelas latas de lixo todas amontoadas no térreo. (ABREU, 2010, p. 97/98)

A letra em itálico evidencia o padrão discursivo epistolar e demonstra o grau de poeticidade da textualidade fragmentária de Caio. Mesclando espaços/tempos e diferentes registros discursivos, sua escritura apresenta a crise do sujeito vivendo na metrópole contemporânea. As várias janelinhas, que estão no campo de visão do narrador, cumprem um papel de metáfora da multidão que compõe a vida da grande cidade. A paisagem urbana, composta pela poluição e pela multidão, provoca um estranhamento no narrador que sofre em viver num espaço esvaziado de sentido, já que não há mais a presença de uma tradição, o que resulta num problema identitário relacionado com a dificuldade de efetivar a sua individualização (LEAL, 2002). Assim, o afeto e a memória se tornam duas dimensões fundamentais para combater a solidão e a tristeza profunda:

Mas foi quando olhei para o espelho que vi o calendário ao lado e aí me veio esse peso no coração, essa lembrança de passo, de setembro e de você. (ABREU, 2010, p. 97)

E se você ainda consegue lembrar daqueles banhos que a gente tomava pelados na sanga Caraguatatá - porque eu, eu não esqueço um segundo nestes sete anos -, mais do que ninguém, você sabe como isso é verdade. (ABREU, 2010, p. 99)

\section{Ensino e teoria}


A solidão e a indiferença acionam a atividade de rememoração de uma experiência vivida com o seu amigo Dudu. A proximidade do aniversário deste reforça a sensação de perda e, consequentemente, a proliferação das lembranças. Os momentos de afeto entre os dois são percebidos a partir de um olhar melancólico do narrador. No final do trecho, a verdade, ao qual se refere a personagem, não reside apenas na veracidade do fato passado na sanga, mas, sim, uma verdade mais profunda relativa à ligação sentimental entre os dois. Nesse sentido, essas lembranças doloridas indicam o modo homoafetivo de existência do narrador e de Dudu, uma vez que, segundo Denilson Lopes (2001), a homoafetividade dá conta de situações cotidianas em que as fronteiras entre amizade e amor aparecem frágeis e permeáveis, se interpenetrando em suas formas de comportamento. Os momentos da sanga com Dudu suscitam, ao mesmo tempo, reminiscências de alegrias e dores na subjetividade do narrador, o que remete para uma afetividade porosa vivida no entre-lugar da amizade e do amor, da dor e da alegria.

O conto apresenta uma segunda parte na qual o regime epistolar cede lugar para a fala confessional do narrador. Alguns elementos caracterizam o lugar de enunciação dessa voz. O corpo masculino é um primeiro aspecto importante. A beleza, a altura, os pelos na pele, a sua cor e os músculos compõe uma forma de apresentação de um masculino que não reforça uma noção de virilidade. Há uma sutileza no detalhamento do corpo, como si este representasse um objeto de desejo dessa voz narrativa: "não sou um cara feio, [...]. verdade que podia ser mais alto um pouco, [...]. e um pouco menos peludo, também podia. De vez em quando tiro a roupa e fico me olhando nu na porta de espelho do guarda-roupa" (ABREU, 2010, p. 99). Em seguida, ele descreve as suas partes peludas; lembra que seu corpo era mais musculoso quando morava na sua cidade, porque ele nadava na sanga; o corpo sadio do passado lhe faz pensar na sua fraqueza do presente que, na verdade, não é física, mas "uma fraqueza por dentro" (ABREU, 2010, p. 100). A fraqueza se relaciona com a ideia de doença. São campos semânticos metafóricos que dizem respeito à condição emocional do personagem: “sei que essa doença não é do corpo" (ABREU, 2010, p.100).

A metáfora da doença engloba a dor da solidão e da perda: o viver só na cidade e a perda de uma intensa relação de afeto com Dudu. As imagens do passado revelam um desencontro, uma situação traumática que expõe uma ferida psíquica sobre a qual emergem os sentimentos de falta e solidão: "a dor doía menos assim, embora não fosse exatamente uma dor. Mais um peso, um calafrio. Uma memória, uma vergonha, uma culpa, um arrependimento em que não se pode dar um jeito" (ABREU, 2010, p. 103).

\section{Ensino e teoria}


A percepção a respeito das vivências pretéritas mostra a projeção de um passado irremediável capaz de se projetar no presente da enunciação como um fardo impregnado de sofrimento. Por outro lado, esses restos mnemônicos prolongam a presença de Dudu na consciência do narrador, representando também um motivo de alegria para este. Dai a situação ambivalente dessa sensibilidade melancólica que reflete a fratura identitária do sujeito da enunciação.

A não superação desse vivido evidencia o estado melancólico dessa voz narrativa, cuja motivação repousa, conforme Agamben (2007), num envolvimento erótico com o objeto perdido. No caso, a experiência junto de Dudu não é superada, acarretando um retraimento da libido que fica atrelado ao objeto perdido. No entanto, este não pode ser novamente apropriado - o real Dudu não existe mais -, o que implica num processo pelo qual o desejo constrói um personagem Dudu fantasmático.

O primeiro índice da irrealidade de Dudu está no fato de que as cartas enviadas pelo narrador não obtêm resposta: "não queria pensar no Dudu agora, mas quando abri a porta e vi a mesinha do corredor vazia - vazia de cartas, [...] sem querer fiquei pensando assim: como seria bom se tivesse uma carta do Dudu” (ABREU, 2010. P. 102). A corporeidade desse objeto ausente demonstra a dimensão amorosa da amizade e dos pequenos encontros, se tornando, depois, ausências que povoam de presença a existência dos sujeitos (LOPES, 2001). Além disso, a indiferença do meio urbano, em que não há laço afetivo, revela uma demanda de alteridade. A voz do narrador, na última parte do conto, se questiona sobre sua tristeza e fala sobre a fragilidade de um amor fácil e sem significado:

Amor picadinho, claro, amor bêbado, amor de fim de noite, amor de esquina, amor com grana, amor com fissura, chato nos pentelhos e doença, nas madrugadas de sábado desta cidade que você não conhece nem vai conhecer. De qualquer jeito, amor, Dudu, embora não mate a sede da gente. (ABREU, 2010, p. 104)

Há uma farta oferta de relacionamento na cidade. Entretanto, não existe envolvimento do desejo nesses amores, elencados pela voz do narrador. São amores descartados, massificados e diluídos na multidão urbana, que não apresentam a marca pessoal do indivíduo, ou seja, que não ficam gravados na sua memória. Por outro lado, o sentimento em relação ao amigo é uma forma de afirmar uma singularidade, não como um identidade fixa, mas um modo de existência descentrado, que vive no entre-lugar da homoafetividade, da amizade e do desejo. Assim, na última parte do conto, de novo sob o domínio epistolar, a voz narrativa relata a situação traumática com o seu amigo:

\section{Ensino e teoria}


Desde aquela tarde quase quente de setembro, quando nos estendemos nus sobre a areia clara das margens da sanga $\mathrm{Ca}$ raguatá, um dia perto do teu aniversário, [...], enquanto uma borboletinha amarela esvoaçava ente nós para escapar depressa no momento exato em que, ali do meu lado, você se debruçou na areia para olhar fundo dentro dos meus olhos, depois estendeu o braço lentamente, como se quisesse me tocar num lugar tão escondido e perigoso que eu não podia permitir o seu olho nos pelos crespos do meu corpo, a sua mão na minh pele que naquele tempo não era branca assim, o seu hálito de hortelã quase dentro da minha boca. Foi então que peguei um daquelas pedras frias da beira d ảgua e plac! Ó, bati de uma só vez na tua cabeça, com toda a força dos meus músculos duros - para que você morresse enfim, e só depois de te matar, Dudu, eu pudesse fugir para sempre de você, de mim, daquele maldito Passo da Guanxuma que eu não consigo esquecer, por mais histórias que invente. (ABREU, 2010, p. 107)

Os momentos de carinho, na beira da sanga, demonstram um envolvimento do desejo. Assim, amor e a amizade se misturam à violência da ação do narrador que matou seu amigo para reprimir uma forma de prazer homoafetiva. Da a condição ambivalente desse sujeito, cuja existência reside na condição intervalar do afeto homoafetivo - englobando aí amizade e amor - e da violência homofóbica.

A construção fantasmática da experiência de afetividade com o personagem Dudu acentua esse caráter intermediário, que é próprio da melancolia, segundo Agamben (2007), uma vez que a indiferença da metrópole impulsiona um movimento de negação do Eu aos objetos externos capaz de conferir um princípio de realidade ao fantasma. O entre-lugar da melancolia não proporciona uma vivência numa fantasia onírica, mas propicia a elaboração de um discurso da dor que possui uma espessura histórica calcada num cotidiano intervalar, no qual as fronteiras entre homossexualidade e heterossexualidade se mostram frágeis e ambíguas, permeadas de afeto e violência. Desse modo, como propõe Denilson Lopes (2001), pode-se pensar numa ética da deriva para essas relações que não se delimitam por espaços identitários fixos, mas que se efetivam por maneiras de relacionamento deslizantes manifestada, por exemplo, na porosidade vivida entre amigos e amantes.

A forma de tradução das experiências desses sujeitos sociais revela um lugar enunciativo marcado pela situação intervalar entre as gramáticas sociais e trajetórias individuais outras. Daí a constituição de uma textualidade ambivalente e ambígua capaz de encenar a situação agônica dos protagonistas. O ato político da enunciação desses sujeitos se concretiza, exatamente, no fato de produzirem uma escrita que narra relações afetivas contrárias ao pacto social estabelecido para

\section{Ensino e teoria}


os comportamentos cotidianos. Portanto, mais importante do que delimitar canais enunciativos fixos e bem demarcados, é fundamental pensar na produção de uma textualidade performática em que o entre-lugar da alteridade cultural provoca o dissenso diante dos dispositivos discursivos de tolerância e consenso das sociedades democráticas.

\section{REFERÊNCIAS}

ABREU, Caio Fernando. Os dragões não conhecem o paraíso Rio de Janeiro: Nova fronteira, 2010.

AGAMBEN, Giorgio. Estâncias: a palavra e o fantasma na cultua ocidental. Tradução de Selvino José Assmann. Belo Horizonte: Editora UFMG, 2007

ALMEIDA, Sandra Regina Goulart. Itinerários de gênero no espaço transnacional. In. O futuro do presente: Arquivo, gênero e discurso. Belo Horizonte: Editora UFMG, 2012. P. 152 -180.

BARTHES, Roland. Aula: aula inaugural da cadeira de semiologia literária do Colégio de França. Tradução e posfácio de Leyla Perrone-Moisés. São Paulo: Cultrix, 2007.

BHABHA, Homi K. O local da cultura. Tradução de Myriam Ávila, Eliana Lourenço de Lima Reis, Gláucia Renate Gonçalves. Belo Horizonte: Ed. UFMG, 1998.

BOURDIEU, Pierre. A dominação masculina. Tradução Maria Helena Kühner. Rio de Janeiro: Bertrand Brasil, 2011.
BUTLER, Judith P. Problemas de gênero: feminismo e subversão da identidade. Tradução Renato Aguiar. Rio de Janeiro: Civilização Brasileira, 2003.

DALCASTAGNÈ, Regina. Uma voz ao sol: representação e

legitimidade na narrativa brasileira contemporânea. In: Estudos de literatura brasileira contemporânea. Número 20 - Brasília, julho/agosto de 2002. P. 33-77.

\section{DIDI-HUBERMANN, Georges. Sobrevivência dos vaga-lumes.} Vera Casa Nova, Márcia Arbex. Belo Horizonte: Editora UFMG, 2011

FOUCAULT, Michel. Microfísica do poder. Organização e tradução de Roberto Machado. Rio de Janeiro: Edições Graal, 1979.

\section{FOUCAULT, Michel. Ditos e escritos, volume V: ética,}

sexualidade, política. Organização Manoel Barros. Tradução Elisa Monteiro, Inês Autran Dourado Barbosa. Rio de Janeiro: Forense Universitária, 2012

\section{GAGNEBIN, Jeanne Marie. História e narração em Walter}

Benjamin. São Paulo: Perspectiva, 2009.

GINZBURG, Jaime. Literatura brasileira: Autoritarismo, Violência, Melancolia. In: GINZBURG, Jaime. Crítica em tempos de violência. São Paulo: Editora da Universidade de São Paulo, 2012. p. $173-187$

GINZBURG, Jaime. A interpretação do rastro em Walter Benjamin. In: GINZBURG, Jaime e SADLMAYER, Sabrina (Org.). Walter Benjamin: rastro, aura e história. Belo Horizonte: Editora UFMG, 2012. p. 107-132.

\section{Ensino e teoria}


HUYSSEN, Andreas. Passados presentes: mídia, política,

amnésia. In: Seduzidos pela memória: Arquitetura,

monumentos, mídia. Rio de Janeiro: Aeroplano, 2000. p. 9-40.

LEAL, Bruno Souza. Caio Fernando Abreu, a metrópole e a

paixão do estrangeiro: contos, identidade e sexualidade em

trânsito. São Paulo: Annablume, 2002.

LOPES, Denílson. Nós os mortos: melancolia e Neo-Barroco. Rio

de janeiro: Sette Letras, 1999.

LOPES, Denilson. Entre-Lugar das Homoafetividades. Ipotesi. Revista de Estudos Literários do Departamento de Letras da UFJF, Juiz de Fora, n.8, p. 37-48, 2001

LOPES, Denilson. Desafios dos Estudos Gays, Lésbicos e

Transgêneros. Comunicação, Mídia e Consumo, São Paulo, p. 6373, 2004.

MIRANDA, Wander Melo. Nações literárias. Cotia, SP. Ateliê Editorial, 2010

RAVETTI, Graciela. Narrativas performáticas. In: RAVETTI, Graciela e ARBEX, Márcia (Org.). Performance, exílio, fronteiras: errâncias territorias e textuais. Belo Horizonte: Departamento de Letras Românicas, Faculdade de Letras, UFMG:PosLit,2002. P. 48-68.

SPIVAK, Gayatri Chakravorty. Pode o subalterno falar? Belo Horizonte: Editora da UFMG, 2010

\section{Ensino e teoria}

